\title{
A case study of snowstorm gusts and blowing/drifting snow
}

\author{
Masayuki Maki, Sento Nakai, Tsuruhei Yagi and Hideomi Nakamura \\ National Research Institute for Earth Science and Disaster Prevention, Tennodai 3-1, Tsukuba, Ibaraki 305, Japan
}

\begin{abstract}
The mechanisms of strong winds associated with snow clouds, and the relationship between strong winds and blowing/drifting snow, were investigated. A snowstorm occurred with a typical L-mode snow band which was generated and organized longitudinally during a continental cold-air outbreak over the Sea of Japan. Doppler radar observations revealed that the snow band consisted of small echo cells arranged along the direction of the snow band. When one of the echo cells passed, blowing/drifting snow was generated and intensified by a snow cloud-induced gust, and the horizontal visibility near the ground surface was significantly decreased. Doppler radar and radiosonde data showed that the gust was due to the cold air outflow (CAO) from the snow clouds. The leading edge of the CAO was about $9 \mathrm{~km}$ ahead of the center of the snow cloud and the depth of the CAO was about $600 \mathrm{~m}$ near the forward flank of the snow cloud. The CAO was caused by a downdraft at the center of the snow cloud, which was initiated at a height of about $1.3 \mathrm{~km}$ and with a velocity in excess of $1 \mathrm{~m} \mathrm{~s}^{-1}$. The observed CAO speed was explained by the theory of the gravity current.
\end{abstract}

\section{INTRODUCTION}

According to the Japanese Society of Snow and Ice (1990), blowing/drifting snow is defined as a phenomenon in which snow particles on the snow cover are moved by a strong wind. Blowing snow and drifting snow are occasionally distinguished in Japan according to the difference in the three types of snow-particle motion: creep, saltation and suspension. When snow particles roll on the snow cover, the movement is defined as creep. When snow particles move by collision and rebound in the surface layer (of the order of a few tens of $\mathrm{cm}$ in depth), the phenomenon is defined as saltation. In the case of suspension, some of the snow particles on the snow cover are blown up to the screen height. In the case of drifting snow, creep and saltation are the dominant motions, while suspension is dominant in the case of blowing snow. Thus, horizontal visibility at the screen height decreases when blowing snow occurs, while it does not decrease in the case of drifting snow. In this paper, we intentionally distinguish between blowing snow and drifting snow.

Blowing/drifting snow occurs when the surface wind exceeds a critical wind speed required to roll and blow up snow particles from the snow cover. Although many studies have been done on the critical conditions of the initiation of blowing/drifting snow (e.g. Ôura and others, 1967; Kind, 1976; Schmidt, 1980), the generation mechanism of a strong wind has not yet been made clear. Strong winds are considered to be related not only to a synoptic pressure pattern, but also to mesoscale weather systems such as the convective snow clouds which form over the Japan Sea in the winter season. In the latter case, strong winds occur unexpectedly and cause an increase in the amount of blowing/drifting snow and a decrease in horizontal visibility near the surface, which is often an obstruction to traffic. The purposes of the present study are to investigate the generation mechanism of snowstorm-induced strong winds and to consider their relation to blowing/drifting snow.

\section{OBSERVATIONS}

Observations were carried out at the Tsugaru Plain in the northern part of Honshu, Japan. Instruments used in the observations were a transportable Doppler radar, low altitude radiosondes and surface meteorological instruments (ultrasonic anemometer-thermometer, thermohygrograph and radiation thermometer). Volume scan data of radar reflectivity, Doppler velocity and Doppler spectrum width were obtained every $10 \mathrm{~min}$ by Doppler radar. Radiosondes were launched every $3 \mathrm{~h}$ to measure vertical profiles of wind speed, wind direction, air temperature and humidity in the lower layers of the atmosphere (up to $3000 \mathrm{~m}$ height). Wind speed, wind direction and air temperature at the height of $5 \mathrm{~m}$ were also measured by ultrasonic anemometer-thermometer and surface temperature was measured by radiation thermometer.

\section{RESULTS OF ANALYSIS}

\section{Synoptic conditions}

Snowstorms occurred on the afternoon of 28 January 1989 when a Siberian air mass overlaid the Japan islands. 


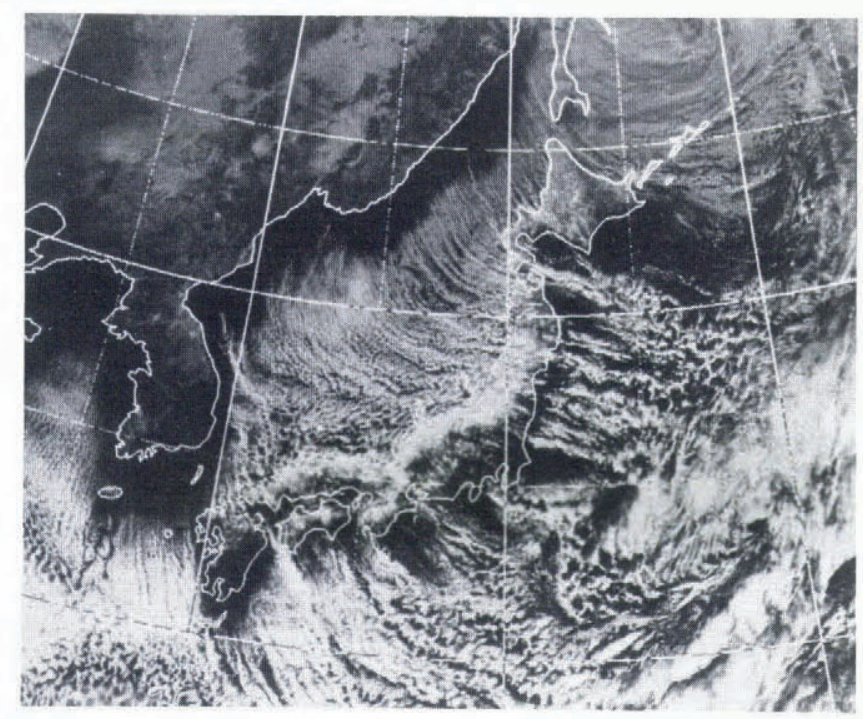

Fig. 1. Visible GMS image of the snow cloud streaks over the Sea of Japan at 12 JST on 28 January 1989.

A visible image of Geostationary Meteorological Satellite (GMS) showed that snow-cloud streaks formed over the Sea of Japan and advanced on the west coast of the Japan islands (Fig. 1). The aspect ratio defined by the ratio of the horizontal scale to the vertical scale of the cloud streak was about 10 . The direction of the snow-cloud streaks was from northwest to southeast and was almost the same as the direction of the cold air outbreak. These clouds have been identified as "Longitudinal mode (L-mode)" snow clouds (Yagi, 1985). Herein, these organized clouds will be referred to as L-mode snow bands or, simply, snow bands. When some of the snow bands were over the observation area, snowstorms and blowing/drifting snow occurred.

\section{Movement of a snow band}

Figure 2 shows the movement of the radar echo of the snow band. According to Boucher and Wexler (1961), the movement of a line-shaped precipitation radar echo can be represented by

$$
C=U_{\mathrm{E}} \sin \alpha+C_{0},
$$

where $C$ is the speed of the line echo, $U_{\mathrm{E}}$ the speed of the individual convective echo elements of the line echo, $\alpha$ the angle between the direction of movement of the line echo and the direction of the movements of the echo elements, and $C_{0}$ the propagation speed due to the generation and dissipation of the echo elements. In the present case, $U_{E}=54 \mathrm{~km} \mathrm{~h}^{-1}, \alpha=20^{\circ}, C=18 \mathrm{~km} \mathrm{~h}^{-1}$, therefore $C_{0}=0 \mathrm{~km} \mathrm{~h}^{-1}$. Thus, the movement of the line echo can be explained by the advection term $U_{E} \sin \alpha$ in Equation (1).

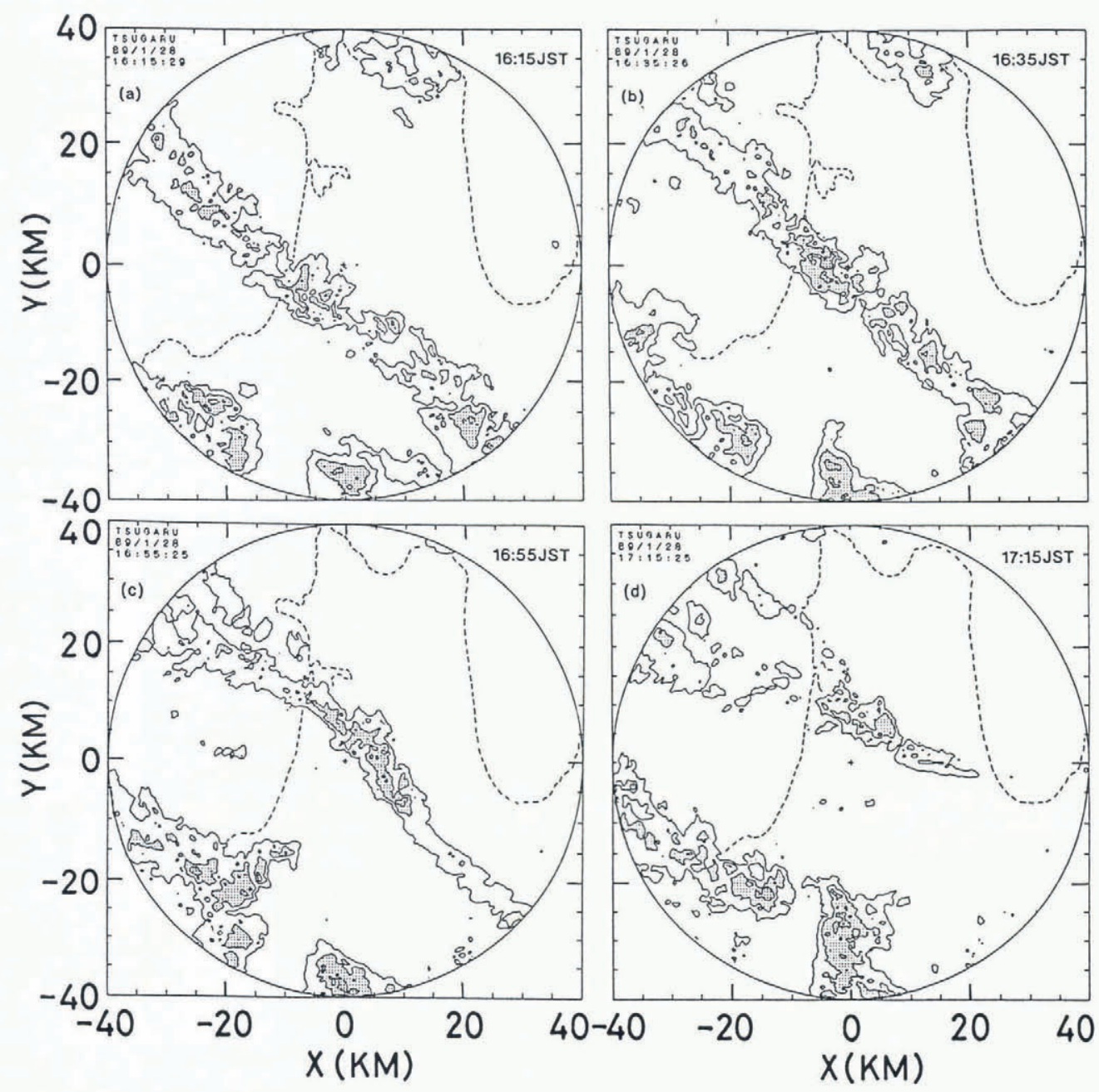

Fig. 2. Movement of the L-mode radar echo. PPI images of the radar reflectivity factor were shown every 20 min. 


\section{Decrease in horizontal visibility at the radar site}

Photographs of the snow bands and horizontal visibility were taken by a camera at the radar site. Although drifting snows, generated locally and intermittently by strong winds, were observed about $40 \mathrm{~min}$ before the arrival of the snow bands, the horizontal visibility exceeded $10 \mathrm{~km}$. On the other hand, when the snow band was over the radar site, a severe snowstorm decreased visibility to less than $10 \mathrm{~m}$. This reduced condition of horizontal visibility lasted until the snow bands had passed over the radar site.

\section{Time change of meteorological elements near the surface}

The change of meteorological elements observed when the snow band passed over the radar site is shown in Figure 3. Time change of the radar reflectivity factor (Fig. 3a) shows that two major echo cells, which composed the snow band, passed over the radar site; one is shown by the peak at 1625 JST (Japan Standard Time) and the other, the highest, at 1645JST. Referring to the PPI (plan position indicator) image of the reflectivity factor (Fig. 4), we can identify the latter peak as the convective echo cell $\mathrm{E}_{1}$ which is just over the
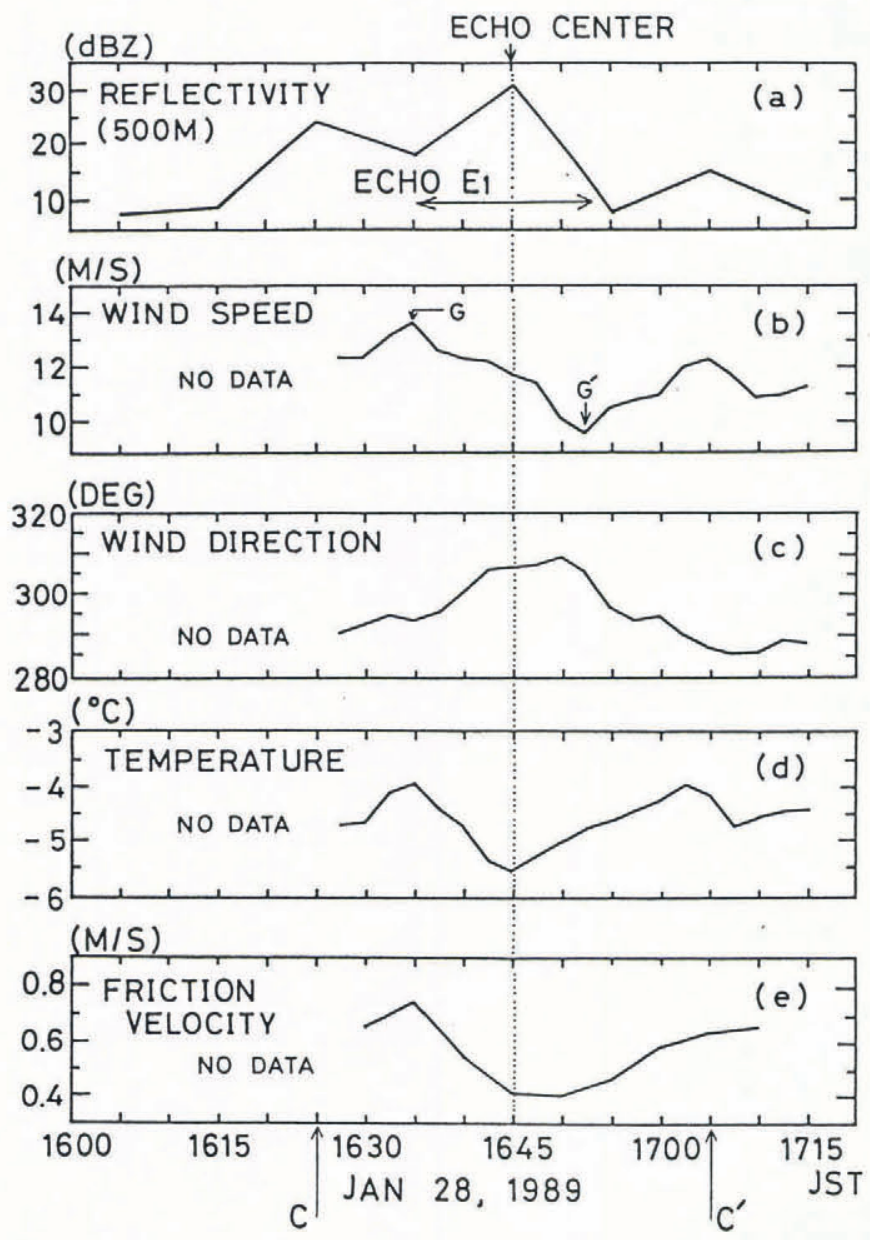

Fig. 3. Time change of: a, reflectivity (in dBZ) at $500 \mathrm{~m}$ height; $b$, wind speed; $c$, wind direction; $d$, air temperature; and e, friction velocity at $5 \mathrm{~m}$ height. Line $C-C^{\prime}$ on bottom shows distance scale estimated by timespace conversion.

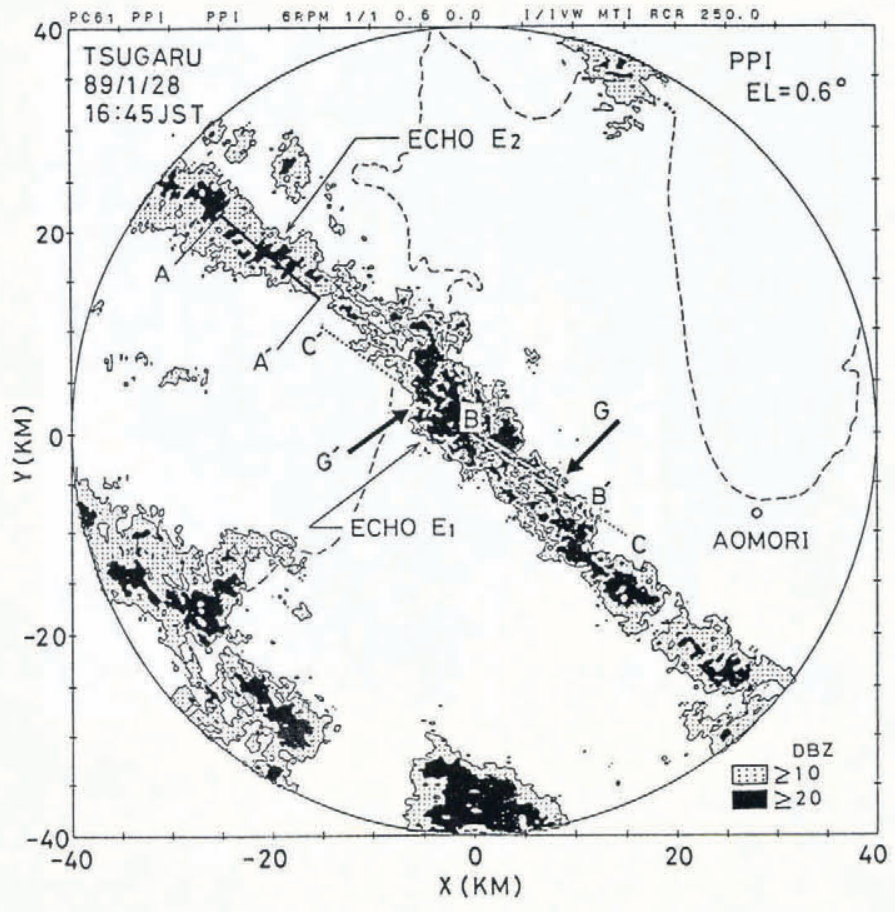

Fig. 4. PPI image of radar reflectivity factor at $1645 \mathrm{JST}$ 28 January 1989. Elevation angle is $0.6^{\circ}$. Heavy dashed line $B-B^{\prime}$ is trajectory of sounding balloon released at point $B$ at 1645. Dotted line $C-C^{\prime}$ corresponds to time change of meteorological elements in Figure 3 from 1625 to 1705 JST. $G$ and $G^{\prime}$ indicate location of the gust and weak wind area obtained by time-space conversion, respectively. $x$ and $y$ are distance east and north from radar, respectively.

radar site. Assuming that the system was in a steady state when it passed over the radar site and that the echo cell moved in accordance with the wind direction in the convective planetary boundary layer (PBL) (shown by the trajectory of sounding balloon $\mathrm{B}-\mathrm{B}^{\prime}$ in Fig. 4), we can convert the time change of the meteorological elements from 1625 JST to 1705 JST (in Fig. 3 ) to the space change along line $\mathrm{C}-\mathrm{C}^{\prime}$ in Figure 4.

One of the interesting features was the time change of the wind speed. A gust of $13.7 \mathrm{~m} \mathrm{~s}^{-1}$ (G in Fig. 3b) was observed at the radar site at $1635 \mathrm{JST}, 10 \mathrm{~min}$ before the arrival of the central part of echo $\mathrm{E}_{1}$. A relatively weak wind speed of $9.6 \mathrm{~m} \mathrm{~s}^{-1}$ ( $\mathrm{G}^{\prime}$ in Fig. $3 \mathrm{~b}$ ) was observed at 1652JST, $7 \mathrm{~min}$ after the passage of the echo center. Considering the echo speed of $54 \mathrm{~km} \mathrm{~h}^{-1}$ and using the time-space conversion, we can state that the gust was located about $9 \mathrm{~km}$ in front of the echo center and the relatively weak wind zone was about $6 \mathrm{~km}$ in back of the echo center. These estimated locations are also shown by $\mathrm{G}$ and $\mathrm{G}^{\prime}$ in Figure 4. Corresponding to the wind-speed change, the friction velocity (Fig. 3e), which expresses the shear force acting on snow particles on the snow cover, was largest at $\mathrm{G}$.

In addition to the change of wind speed, an air temperature change was observed (Fig. 3d). While the air temperature was the lowest $\left(-5.5^{\circ} \mathrm{C}\right)$ at the echo center, it was about $-4^{\circ} \mathrm{C}$ when the gust was observed. The maximum drop in air temperature was about $1.5^{\circ} \mathrm{C}$. This air temperature change is similar to that observed 
with a thunderstorm-induced gust, which is well known to be caused by a downdraft from a well developed cumulonimbus (e.g. Goff, 1976; Wakimoto, 1982). A downdraft reaching the surface diverges and travels as a cold air outflow (CAO). When a low-level downdraft is intense and produces a damaging outflow wind, it is called a downburst (Fujita, 1981). In the case of snowstorms, though the strength of a downdraft and a

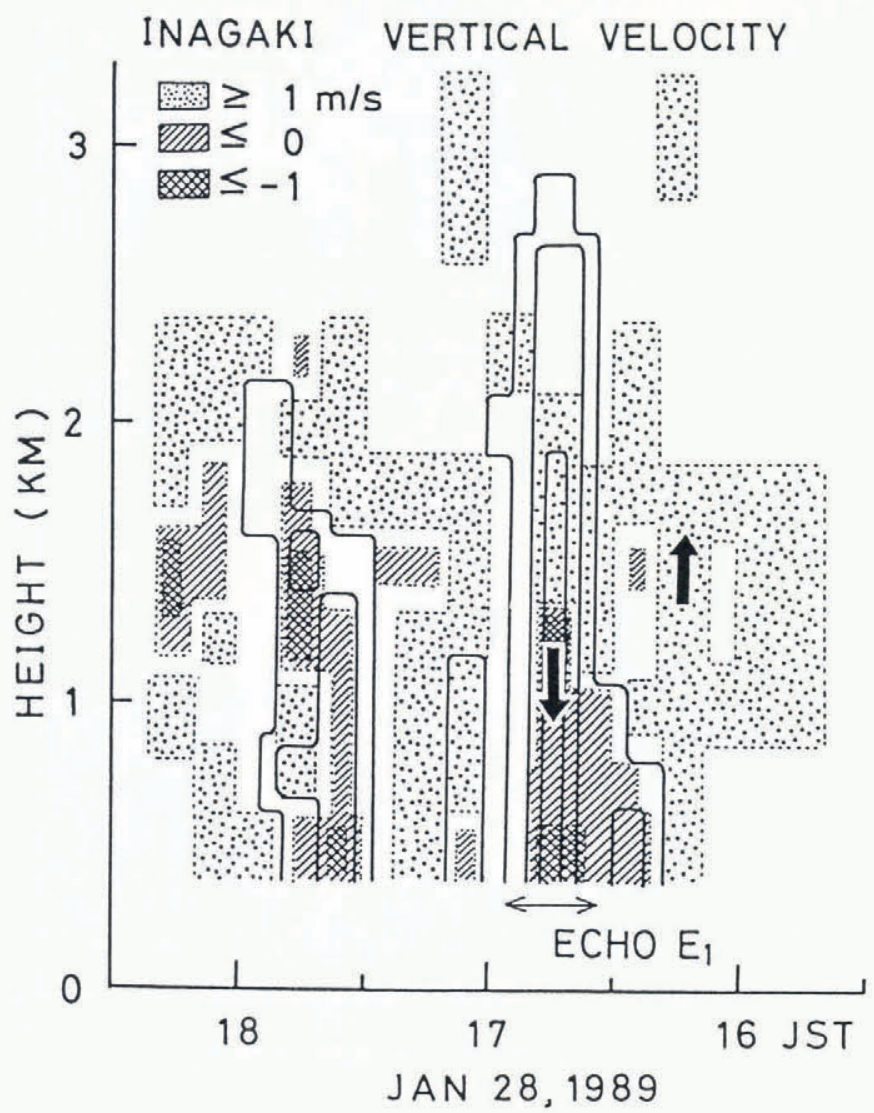

Fig. 5. Time-height cross-section of vertical velocities and radar reflectivity factor of radar echo cell $E_{l}$. Contours are radar reflectivity factors from $10 \mathrm{dBZ}$ at every $5 \mathrm{dBZ}$. Time direction is from right to left.

WIND SPEED

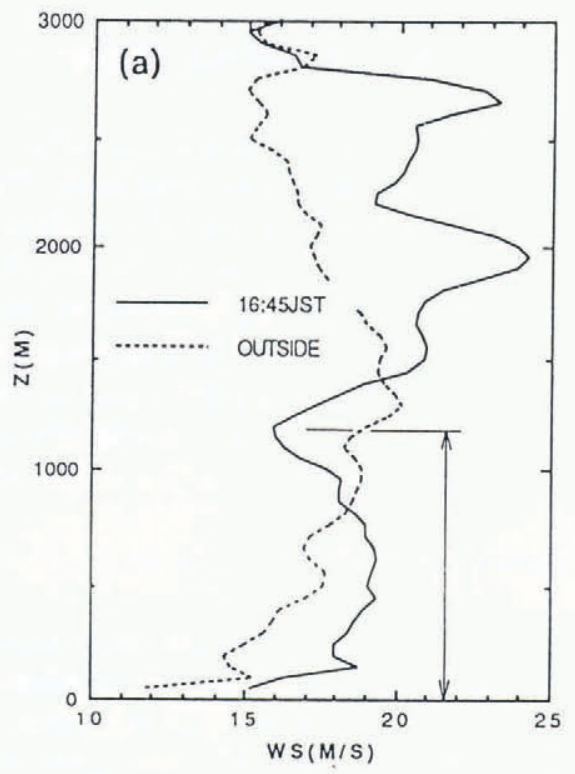

CAO may be weaker than those of thunderstorms, similar processes can be supposed. Therefore, we next investigated the downdraft in the snow band and the existence of the CAO.

\section{Downdraft}

When the snow band passed over the radar site, we measured the vertical profiles of the radar reflectivity factor and Doppler velocity by pointing the antenna vertically. The distribution of the vertical compoment of wind speed $w$, or downdraft, superimposed on the timeheight cross-section of the radar reflectivity factor is shown in Figure 5. The Doppler velocity $w_{\mathrm{d}}$ measured by the vertical-pointing mode of the antenna is the sum of the vertical component of wind speed $w$ and the fall speed of snow particles in still air $w_{\mathrm{t}}$. Referring to Battan (1973), we used the value $1 \mathrm{~m} \mathrm{~s}^{-1}$ for $w_{\mathrm{t}}$ to obtain $w$. The updraft and downdraft greater than $1 \mathrm{~m} \mathrm{~s}^{-1}$ are shown by the stippled area and cross-hatched area, respectively. Echo $\mathrm{E}_{1}$ passed over the radar site between 1635 and 1655 JST. Assuming a steady state of echo $\mathrm{E}_{1}$ during this period, we can derive the structure of the vertical wind speed field of echo $\mathrm{E}_{1}$ by the time-space conversion, as used in Figure 3. Again, the time change corresponds to direction $\mathbf{C}-\mathrm{C}^{\prime}$ in Figure 4. Although the time resolution of Figure 5 was $10 \mathrm{~min}$, the following facts were noted. There was a downdraft at the echo center. This downdraft began at the height of $1.3 \mathrm{~km}$ and its strength was larger than $1 \mathrm{~m} \mathrm{~s}^{-1}$. On the other hand, an updraft was observed near the forward flank of the echo and in the layer above the height of $1.3 \mathrm{~km}$ at the echo center. There was also a downdraft over $1 \mathrm{~m} \mathrm{~s}^{-1}$ in the other echo cell observed after 1700 JST.

\section{Snowstorm-induced gust}

Vertical wind profiles were obtained before, during and after the snow band passed over the radar site. An averaged profile of two soundings at 1450 and $1748 \mathrm{JST}$ is shown by the dotted line in Figure 6 . This profile can be

WIND DIRECTION

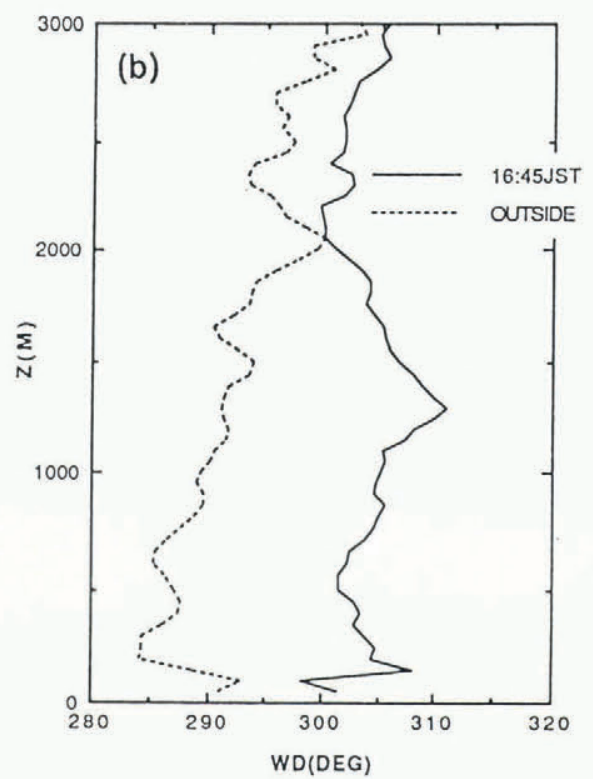

Fig. 6. Vertical profiles of $a$, wind speed, and b, wind direction. Solid line shows profile observed at 1645 JST. Dotted line shows averaged profile of soundings at 1450 and 1748 JST. 
regarded as the wind field outside the snow band. On the other hand, as seen from the trajectory $\mathrm{B}^{-} \mathrm{B}^{\prime}$ of a sounding balloon (Fig. 4), the wind profile at $1645 \mathrm{JST}$ gives us information of the wind field near the forward flank of echo $E_{1}$. The wind profile outside the snow band has a jetstream shape: the wind profile has its maximum value at $1300 \mathrm{~m}$ height and an inflection point at $2600 \mathrm{~m}$ height. This type of vertical wind profile is generally observed when an L-mode snow band is formed. Contrary to this, the wind profile at $1645 \mathrm{JST}$ shows that there was a wind speed maximum of about $20 \mathrm{~m} \mathrm{~s}^{-1}$ at a height of $1300 \mathrm{~m}$. The wind direction at that time was almost uniform to $3000 \mathrm{~m}$ height and any noticeable change in the wind direction near $500 \mathrm{~m}$ height cannot be recognized. According to the vertical air temperature profile shown in Figure 7, the air temperature at $1645 \mathrm{JST}$ was colder than the averaged profile of two soundings at 1450 and $1748 \mathrm{JST}$ in the layer below $600 \mathrm{~m}$ height. The temperature difference was about $1.5^{\circ} \mathrm{C}$ near the ground. These observations suggest the existence of a cold air outflow (CAO) from the snow cloud.

Furthermore, to substantiate the existence of the CAO, we investigated the Doppler wind field of echo $\mathrm{E}_{2}$. The radar reflectivity factor and horizontal wind speed on the vertical cross-section of echo $\mathrm{E}_{2}$ are shown in Figure 8. The direction of the cross-section corresponds to the wind direction in the convective PBL. Echo $\mathrm{E}_{2}$ moved from left to right in Figure 8. Slash marks show the layer where the system-relative forward flow was greater than $0.5 \mathrm{~m} \mathrm{~s}^{-1}$. This area was observed to be a gust area near the ground. The depth of this layer is about $1000 \mathrm{~m}$ at the center part of echo $E_{2}$ and it decreases at the forward flank of the echo. Stippling shows the layer where the system-relative backward flow was greater than $0.5 \mathrm{~m} \mathrm{~s}^{-1}$. This area was observed to be a relatively weak wind area near the ground. Although this flow pattern was obtained in echo $E_{2}$, it is consistent with the results obtained by radiosonde observation (Fig. 6).

\section{TEMPERATURE}

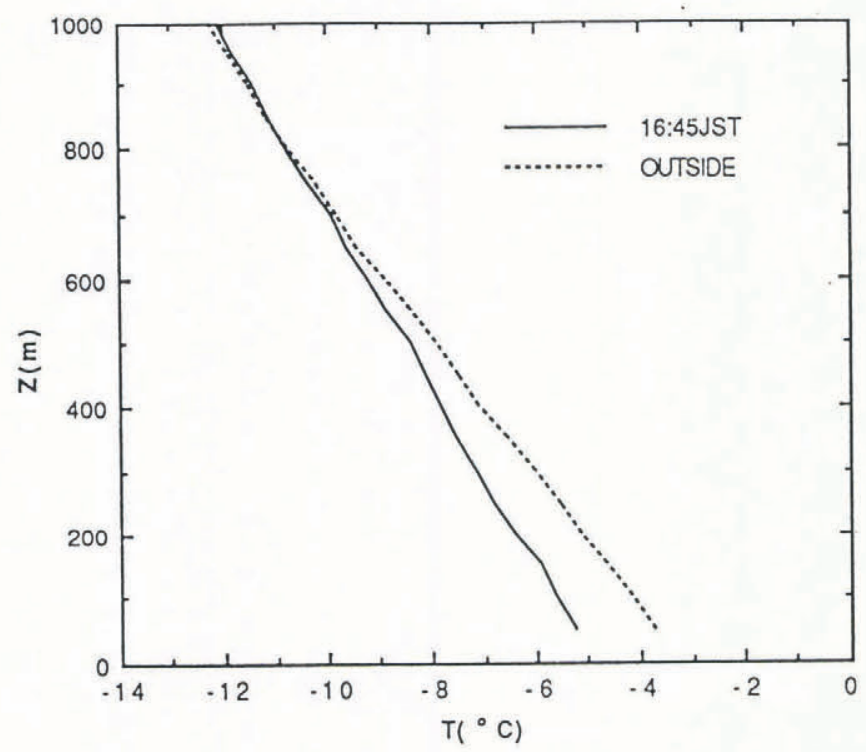

Fig. 7. Vertical air temperature profile, as in Figure 6 .
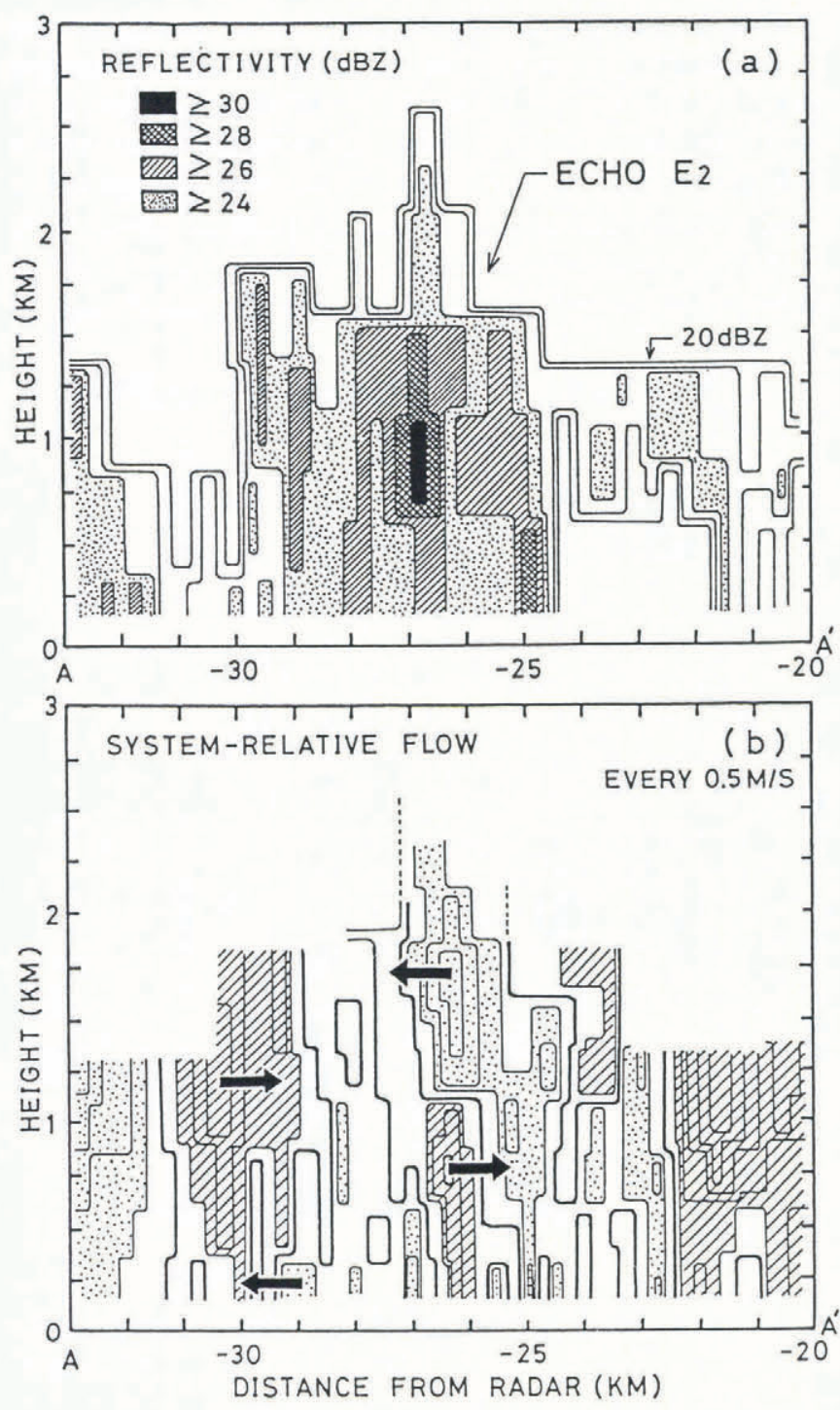

Fig. 8. Vertical cross-sections of $a$, reflectivity, and $b$, cellrelative wind of radar echo cell $E_{2}$. Two dimensionality of wind field of echo $E_{2}$ was assumed on vertical cross-section along line $A-A^{\prime}$ in Figure 4.

\section{SUMMARY AND DISCUSSION}

The flow structure associated with a snowstorm was clarified from the present case study. The major points of the results of analysis were the existence of a snowstorminduced gust, the cold air outflow (CAO) from the snow cloud and the downdraft at an echo center. In addition to these facts, we discuss the following items to understand better the generation mechanism of the snowstorm gust and its relationship to blowing/drifting snow, and we identify problems to be solved in the near future.

\section{Structure of the snowstorm}

The structure of the L-mode snow bands analyzed in the present study was investigated by Maki and others (1992) by using three-dimensional computer graphics. According to their analysis, the snow band was about $10 \mathrm{~km}$ in width and had a direction which corresponded to the wind direction in the convective PBL. The snow band was 
composed of small convective echo cells arranged in the band direction with about a $5 \mathrm{~km}$ interval. The maximum echo height was about $3 \mathrm{~km}$.

\section{Cold air outflow (CAO) as the density current}

It is known that a CAO from a well developed thunderstorm forms a gust front. This CAO has a characteristic density current (e.g. Simpson, 1969; Charba, 1974; Simpson and Britter, 1980). According to the theory of density current (e.g. Simpson, 1969), its speed is expressed by

$$
C=k\left(g h \frac{\left(\rho_{0}-\rho_{1}\right)}{\rho_{1}}\right)^{\frac{1}{2}}=k\left(g h \frac{\left(T_{1}-T_{0}\right)}{T_{0}}\right)^{\frac{1}{2}},
$$

where an approximation $\rho_{0} / \rho_{1} \approx T_{1} / T_{0}$ is used. In Equation (2), $g$ is the gravitational acceleration, $h$ the depth of the CAO, $\rho_{0}$ the air density inside the CAO, and $k$ the square root of the internal Froude number which is the ratio of the internal force to the gravitational acceleration force and has a value between 0.6 and 1.3. Substituting observed values $\left(T_{1}-T_{0} \approx 1.5 \mathrm{~K}\right.$, $T_{0} \approx 268 \mathrm{~K}, h \approx 600 \mathrm{~m}$ ) into Equation (2) and assuming $k=1$, we obtained $C \approx 5 \mathrm{~m} \mathrm{~s}^{-1}$. Assuming the moving speed of the echo was about $15 \mathrm{~m} \mathrm{~s}^{-1}$, the gust estimated by the density current theory is about $20 \mathrm{~m} \mathrm{~s}^{-1}$. This value corresponds to the observed wind speed near $500 \mathrm{~m}$ height (Fig. 6a).

\section{Generation mechanism of the downdraft}

It is important to study the generation mechanism of downdraft because it determines the strength of a CAO and a gust. Two mechanisms can be considered for the downdraft: drag force of falling snow particles and diabatic cooling caused by sublimation and melting of the particles. The latter mechanism is driven by the relatively dry air inflow at the middle layer of the echo: there was air flow from left to right at $1000 \mathrm{~m}$ height at the rear flank of echo $\mathrm{E}_{2}$ in Figure $8 \mathrm{~b}$. Sakakibara and others (1988) observed a similar inflow in convective snow bands. Although the strength of the downdraft is less than $2 \mathrm{~m} \mathrm{~s}^{-1}$ in the present case and less than $3 \mathrm{~m} \mathrm{~s}^{-1}$ in the observations by Sakakibara and others (1988), a downdraft of $10 \mathrm{~m} \mathrm{~s}^{-1}$ was reported by Shirooka and Uyeda (1990). To understand the generation mechanism of a downdraft more quantitatively, additional observations and numerical experiments will be necessary.

\section{Relationship between snowstorm gust and blowing/drifting snow}

As mentioned in the introduction, blowing snow and drifting snow are sometimes distinguished in Japan according to the difference in the types of snow-particle movements. Here, we accept this terminology to discuss the relationship between their occurrences and the snowstorm gust.

The strength of a gust is not the only factor which determines the type of snow-particle movement: snow surface condition, especially temperature, is also important. According to Oura and others (1967), the critical

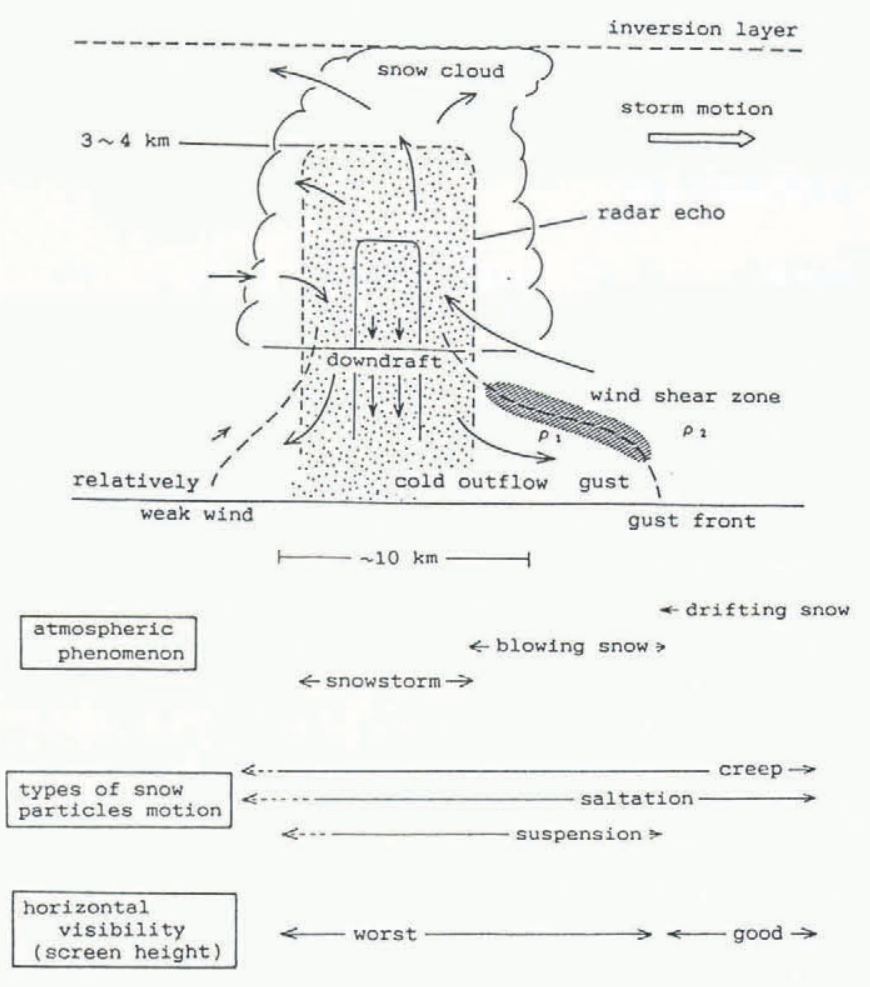

Fig. 9. Conceptual model which explains the relationship between a snowstorm gust and blowing/drifting snow. In the flow pattern, interaction among convective cells of the snow band is not considered. Types of snow-particle movements and extent of decrease in horizontal visibility at the screen height are also shown at bottom.

wind speed for the occurrence of drifting snow is about $8 \mathrm{~m} \mathrm{~s}^{-1}$ when the air temperature near the snow cover is around $-4^{\circ} \mathrm{C}$. According to the observations by Takeuchi and others (1986), a critical wind speed for the generation of continuous blowing snow is about $11 \mathrm{~m} \mathrm{~s}^{-1}$. Applying these results to the present case, we derived a conceptual model which explains the relationship between a snowstorm gust, blowing snows and drifting snows (Fig. 9). In the present case, it can be estimated that there were intermittent drifting snows outside the CAO, continuous blowing snows and drifting snows inside the $\mathrm{CAO}$ region, and intermittent weak drifting snows at the relatively weak wind area at the rear flank of the echo. In the center part of the echo, snowfall from the snow cloud was added to the blowing/drifting snow and decreased the horizontal visibility. In Figure 9, variation in the horizontal visibility is also shown schematically.

The conceptual model shown in Figure 9 is limited because the location and strength of the snowstorm gust depend not only on the types of snow clouds but also on the stages of development. Thus, we need to investigate the other cases, such as a single convective snow cloud and/or a transversal snow band at various stages, to obtain a more generalized model.

\section{ACKNOWLEDGEMENT}

We should like to express our grateful thanks to the local 
public officials at the Inagaki Village Office of Aomori Prefecture who extended their kind support to us.

\section{REFERENCES}

Battan, L.J. 1973. Radar observation of the atmosphere. Chicago, IL, University of Chicago Press.

Boucher, R.J. and R. Wexler. 1961. The motion and predictability of precipitation lines. F. Meteorol., 18, 160-171.

Charba, J. 1974. Application of gravity current model to analysis of squall-line gust front. Mon. Weather Rev., 102, 140-156.

Fujita, T.T. 1981. Tornadoes and downbursts in the context of generalized planetary scales. F. Atmos. Sci., 38, 1541-1580.

Goff, R.C. 1976. Vertical structure of thunderstorm outflows. Mon. Weather Rev., 104, 1429-1440.

Japanese Society of Snow and Ice, ed. 1990. Seppyo Jiten. Tokyo, Kokon Syoin. [In Japanese.]

Kind, R.J. 1976. A critical examination of the requirements for model simulation of wind-induced erosion/ deposition phenomena such as snow drifting. Atmos. Environ., 10(3), 219-227.

Maki, M., H. Ohkura and T. Mikoshiba. 1992. Applications of 3 dimensional computer graphics to the Doppler radar data processing. Report of the National Research Institute for Earth Science and Disaster Prevention 49, 53-64. [In Japanese with English summary.]

Ôura, H., T. Ishida, D. Kobayashi, S. Kobayashi and T. Yamada. 1967. Studies on blowing snow II. In Ôura, H., ed. Physics of snow and ice. International Conference on
Low Temperature Science ... 1966 ... Proceedings. Vol. 1. Part 2. Sapporo, Hokkaido University. Institute of Low Temperature Science, 1099-1117.

Sakakibara, H., M. Ishihara and Z. Yanagisawa. 1988. Squall line like convective snowbands over the Sea of Japan. 7. Meteorol. Soc. Fpn, 66(6), 937-953.

Schmidt, R.A. 1980. Threshold wind-speeds and elastic impact in snow transport. F. Glaciol., 26(94), 453-467.

Shirooka, R. and H. Uyeda. 1990. Morphological structure of snowburst in the winter monsoon surges. J. Meteorol. Soc. Jpn, 68(6), 677-686.

Simpson, J.E. 1969. A comparison between laboratory and atmospheric density currents. Q F. R. Meteorol. Soc., 95, 758-765.

Simpson, J.E. and R.E. Britter. 1980. A laboratory model of an atmospheric mesofront. Q F. R. Meteorol. Soc., 106, 485-500.

Takeuchi, M., K. Ishimoto, T. Nohara and Y. Fukuzawa. 1986. Dynamic threshold wind speed for suspension. Proceedings of the annual meeting of the Japanese Society of Snow and Ice. 252. [In Japanese.]

Wakimoto, R.M. 1982. The life cycle of thunderstorm gust fronts as viewed with Doppler radar and rawinsonde data. Mon. Weather Rev., 110, 1060-1082.

Yagi, S. 1985. Large scale snow clouds with roll axes roughly perpendicular to the direction of winter monsoon burst: observational studies of convective cloud roll axes and some theoretical consideration. Tenki, 32, 175-187. [In Japanese.]

The accuracy of references in the text and in this list is the responsibility of the authors, to whom queries should be addressed. 